\title{
Obstructions and Efforts to Create Port Efficiency in the Perspective of Business Competition Law
}

\author{
Sutanto ${ }^{1}$, Rineke Sara ${ }^{2}$ \\ $\left\{\right.$ tant.associates@gmail.com ${ }^{1}$,rineke_sara@borobudur.ac.id $\left.{ }^{2}\right\}$ \\ Universitas Borobudur, Jakarta, Indonesia ${ }^{1,2}$
}

\begin{abstract}
This examination intends to recognize and dissect the snags that cause shortcomings in strategic policies at ports that are uncalled for business rivalry and analyze legitimate cures that can be taken. This kind of exploration standardizes honest examination. There are a few methodologies utilized in this exploration. The lawful interaction to monetary review and regularizing juridical framework. This exploration uses auxiliary information, including essential legitimate materials, optional legal materials, and lawful tertiary materials. In light of the conversation, the essayist can depict a few ends. That there are a few types of strategic approaches and governance arrangements that, eventually, can cause failure in ports. These obstructions are isolated into two properties. The first is juridical obstructions, and the second is non-juridical boundaries. Juridical impediments remember hindrances from government arrangements for the type of guidelines identified with strategic policies in ports and infringement of rivalry law. In the interim, non-juridical obstructions, for example, business structures that permit administrators to play double parts other than as administrators, the powerlessness of the private area to contribute and the event of unlawful exact, so the expenses caused are charged to products which trigger high costs. As an answer for these issues, a few endeavors can be taken. Legitimate endeavors that can be taken to make productivity in ports are law requirements against guidelines that are considered satisfactory, however not yet decisive, trailed by streamlining the job of establishments that have the position to complete oversight.
\end{abstract}

Keywords: obstacles; efforts; business competition; ports

\section{Introduction}

As an archipelagic country whose territory consists of a vast stretch of water and has an island distribution of up to 17,508 , business activities in the shipping sector certainly have a crucial role in Indonesia. One of its manifestations is increasing quantity and quality to distribute national logistics, both domestically and internationally available logistics. In other words, not only as a support for socio-cultural interests, politics, and defense and security, commercial activities in ports, of course, can support the country's economic development.[1]

The logistics sector plays a vital role in national development and increasing trade competitiveness within a country. A well-run and effective logistics system can lead to more 
efficient distribution channels of goods, services, and information from the point of departure to consumption.[2] On the other hand, a poor logistics system can reduce incentives and trade value. For this reason, all business practices related to logistics that are unhealthy and monopolistic need to be eliminated. There is becoming increasingly urgent, especially after Indonesia ratified the ratification of the World Trade Organization through Law Number 7 of 1994, one of which is the General Agreement on Trade and Services.[3] In a free-market framework, if the shipping service industry is inefficient and cannot compete fairly, the entire industry activity will be inefficient. Law Number 5 of 1999 concerning the Prohibition of Monopolistic Practices and Unfair Business Competition was established as a commitment to realize the goal of efficiency.[4]

The structuring of the logistics sector has become a concern for the government, especially since Indonesia and ASEAN countries signed the ASEAN Sectoral Integration Protocol for the Logistic Services Sector in August 2017.[5] The understanding prompted the total incorporation and advancement of the coordination administrations area in ASEAN. Especially in shipping business activities, one of the pillars of logistics distribution in Indonesia, the spirit to create a healthy business competition climate is included in Law Number 17 of 2008 concerning Shipping.[6] As mentioned in the preamble, one of the considerations for establishing this law is to regulate the participation of local governments and private entrepreneurs to improve performance in the port sector to create a climate of healthy business competition that will certainly eliminate the risk of high costs.[7]

Law No. 17 of 2008 was initially expected to be effective on May 7, 2001, Several issues that are still an obstacle in realizing a healthy business competition climate in its implementation have been efforts, one of which is the separation between operators and regulators. PT. Pelabuhan Indonesia (Pelindo), a Port Business Entity that previously acted as an operator and a regulator, is now no longer a regulator. Pelindo is positioned as a Terminal Operator and must have a Port Business Entity Permit. Meanwhile, the regulator is held by the Port Authority, which used to be the Port Administrator.[8]

As regulated by Law Number 17 of 2008 and Government Regulation Number 61 of 2009, the Port Authority is a government institution at the port that carries out regulating, controlling, and supervising commercially managed port activities. The Port Authority also acts as a government representative to grant concessions or other forms to the Port Business Entity to carry out business activities at the port as stated in the agreement.

Problems arise because, until 2021, the aspects that have been regulated have not been implemented. The Port Authority has not yet carried out its role as an authoritative body representing the State in granting concessions to Port Business Entities, either in nearby legislatures, state-possessed undertakings, or the private area, to carry out business at the port. In addition, there is also a problem with Pelindo, which still seems to act as a regulator. There is, of course, contrary to the existing regulations because the OP should regulate, control, and supervise port activities managed on a commercial basis.

The position held by Pelindo in the period before the enactment of Law Number 17 of 2008 as the only operator, regulator, and business actor to date has not changed in practice as regulated by Law Number 17 of 2008. In addition, Pelindo also has subsidiaries established to conduct business in ports such as BJT at Tanjung Perak port and JTCT at Tanjong Priok port. Such a position indeed results in Pelindo and other companies related to Pelindo having a very dominant position. From an economic perspective, the dominant position as described will undoubtedly lead to inefficiency, contrary to the principles and objectives of Law Number 5 of 1999. 
If the concession has not been implemented, Paul Kent believes that Law Number 17 of 2008 is still creating confusion until now. It is as if the law still maintains the status quo of BUP, which was the regulator and the sole operator in the period before the promulgation of Law Number 17 of 2008, and there is no precise time limit. Although this law explicitly allows local governments and the private sector to participate in managing the port. However, this factor was also caused by the Letter of the Minister of Transportation Number HK 003/1/11 Phb 2011, which appointed PT Pelabuhan Indonesia I, 11, III, and IV (Persero) as temporary implementers but was not given a time limit.

Another indicator that illustrates unhealthy business practices that cause inefficiency is that apart from being an operator, Pelindo also acts as a business actor who competes with other companies that do not act as operators. The practice of loading and unloading is one of them. Pelindo is a provider of land for loading and unloading activities and carries out loading and unloading business practices, while loading and unloading companies outside Pelindo also use Pelindo terminal services to carry out their business activities. There is where the potential for conflict of interest arises. The potential for unfair business competition that is inefficiency from an economic perspective is very likely to occur.

The problems mentioned above are some of the facts that require resolution. One discussion deemed appropriate to reference is economic and legal approaches as a blend of goals and tools to achieve goals. Even though it has exceeded the time limit determined regarding its implementation, Law No. 17 of 2008, in which several rules have not been implemented, is still considered a transitional period. Due to the complexity of existing shipping business activities, one of which is the port problem.

Efficiency in the structure of business actors at the port is a necessity. Therefore, this thesis will examine the obstacles in realizing efficiency at ports, such as implementing Law No. 17 of 2008, which makes it challenging to create efficiency to create a healthy business climate in the port sector. In addition, it will also examine the legal and non-legal mechanisms that can be taken to overcome these problems. This effort is essential to increase the role of port, or as one of the supports for logistics distribution, which significantly influences the country's economy.

\section{Methods}

The type of legal research used in this research is normative legal research.[9] Issues that become problems are described, and the existing laws and doctrines are sought to answer issues considered legal problems.[10]

Several approaches will be used in this research: the approach used in this research is the legal approach to economic analysis. It is used because the science of law is a science that seeks to adapt to other matters to reach the scope of specific problems - a normative juridical approach. Normative legal research must use a guide or statutory approach because what will be analyzed are problems viewed from various legal rules that are the focus and the central theme of a study.

This research focuses on indications of inefficiency in business practices at ports and legal remedies that can be taken to overcome them. In addition, institutions considered to have links include the Port Authority as a regulator with authority in a shipping business activity site, namely the port, and the Port Business Entity, which regulates shipping business activities to collect data and information. 
This study will use secondary data, including primary, secondary, and tertiary legal materials. The primary legal materials are Law No. 17 of 2008 and Law No. 5 of 1999 as the problem analysis tools raised. Secondary legal materials are sourced from legal materials in documents, books, journals, other relevant supporting literature. At the same time, tertiary legal materials are sourced from the required encyclopedias and dictionaries. To add to the legal materials, interviews were conducted with respondents.

\section{Discussion}

\subsection{Business Competition in Indonesia}

During the New Order government, the implementation of the national economy was seen as tending to support the monopolistic pattern of business competition. At that time, people in business who were close to the power elite got a lot of conveniences, so that it had an impact on social inequality. Conglomerates and groups of strong entrepreneurs without a true entrepreneurial spirit become prominent factors that cause economic resilience to become unfavorable and unable to compete.[11]

Some regulations specifically regulate Sam's business competition in Indonesia itself, which emerged in 1999 through Law Number 5 of 1999 concerning the Prohibition of Monopolistic Practices and Unfair Business Competition. The law was effective only in 2000. Apart from being a demand for national needs, competition law in Indonesia is also needed as a form of economic relations between nations. There is also a consequence of Indonesia's joining the World Trade Organization (WTO).

The economic crisis occurred in 1997-1998. In the recovery effort, one of the passions that emerged was to create economic development directed towards realizing people's welfare based on Pancasila and the 1945 Constitution and following Indonesia's commitment to international agreements. The economic reforms carried out include structuring and rearranging domestic economic activities by changing the high-cost economic climate into a more healthy, open, competitive, effective, and efficient economic climate. Based on this spirit, the government took concrete steps by enacting Law Number 5 of 1999 concerning the Prohibition of Monopolistic Practices and Unfair Business Competition.[12]

The order of Law Number 5 of 1999 is to defeated monopolistic practices and uncalled for business contest in monetary exercises in Indonesia. In light of Article 1 section 1, Monopoly is command over the creation and additionally promoting of products or potentially the utilization of explicit administrations by one business entertainer or a gathering of business entertainers. Syndication practice is the grouping of monetary power by at least one business entertainers, which brings about the control of creation and showcasing of explicit labor and products to make uncalled for business rivalry and mischief the public interest.

While the extent of the law is as market-related activities that should be controlled by the antitrust law, which is additionally the extent of the antitrust law, specifically precluded arrangements, restricted exercises, maltreatment of predominant position, the Business Competition Supervisory Commission.Procedures for handling cases and sanctions. However, in this chapter, the scope described is only related to the prohibition of prohibited agreements, activities, and dominant position abuse.

Based on Law Number 5 of 1999, in chapter 111, there are 10 (ten) types of agreements that are prohibited, namely: 


\section{a) Oligopoly}

Business entertainers are denied from going into concurrences with other business entertainers to mutually control the creation and promoting of labor and products, bringing about monopolistic practices and uncalled for business rivalry. Business entertainers ought to be suspected or considered to have mutually controlled the creation or potentially promoting of merchandise as well as administrations, as alluded to in section (I) if 2 or 3 business actors or groups of business actors control more than $75 \%$ of the market share of one type of goods or services. Certain.

\section{b) Pricing}

Business actors are prohibited from entering into agreements with competing business actors to determine the quality of goods and services that consumers or customers must pay in the same relevant market. The provisions in paragraph (1) do not apply to an agreement entered into in a joint venture or based on applicable law.

\section{c) Territory Division}

Business actors are prohibited from entering into agreements with business competitors to divide marketing areas or market allocations for goods and services, resulting in monopolistic practices and unfair business competition.

\section{d) Boycott}

Business entertainers are restricted from going into concurrences with contending business entertainers, keeping other business entertainers from leading a similar business, both for homegrown and unfamiliar business sectors. Business entertainers are denied from going into concurrences with contending business entertainers to decline to sell any merchandise as well as administrations from other business entertainers so that such activities are negative or can be associated with hurting other business entertainers, or limit other business entertainers from selling or purchasing any products or potentially benefits from the applicable market

\section{e) Cartel}

Business entertainers are disallowed from going into concurrences with business contenders to impact costs by managing the creation and promoting of labor and products, bringing about monopolistic practices and unjustifiable business rivalry.

\section{f) Trust}

Business entertainers are denied from going into concurrences with other business entertainers to participate by shaping a joint organization or bigger organization while keeping up with and keeping up with the practicality of each organization or its part organizations, which plans to control the creation or potentially promoting of merchandise as well as administrations, which might bring about monopolistic practices and additionally uncalled for business rivalry. 


\section{g) Oligopsony}

Business actors are prohibited from entering into agreements with other business actors to jointly control the purchase or receipt of supplies to control the prices of goods and services in the relevant market, resulting in monopolistic practices and unfair business competition.

\section{h) Vertical Integration}

Business actors are prohibited from entering into agreements with other business actors to control the production of some products that are included in the production series of certain goods and or services in which each production series is the result of processing or further processing, either in a direct or indirect series, which may result in unfair business competition and detrimental to society.

\section{i) Closed Agreement}

Business actors are prohibited from entering into agreements with other business actors containing a requirement that the party receiving the goods and services will only supply or not resupply the goods and services to certain parties and or at certain places.

\section{j) Agreements with foreign countries}

Business actors are prohibited from entering into agreements with other parties abroad that contain provisions that may result in monopolistic practices and unfair business competition.

\subsection{Barriers to Creating Efficiency in Indonesian Ports}

From the various descriptions and studies conducted, the author considers that several things become obstacles in creating a climate of fair business competition that causes inefficiency in Indonesian ports. The writer divides these barriers into two characteristics.[13] First, the juridical barriers so that some of these obstacles are related to policies issued by the government, such as the difficulty of implementing Law Number 17 of 2008 concerning Shipping which is intended to create a climate of fair business competition and the emergence of several other regulations that are counterproductive with the aim to be achieved. In addition, there are non-juridical obstacles, such as the inability of the private sector to meet capital requirements to be able to compete with the previous rulers (status quo). Some of the things that become obstacles include:

\section{a) Public Policy}

At the ASEAN regional level, logistics services are one aspect that is promoted for liberalization through the ASEAN Sectoral Integration Protocol for the Logistic Services Sector. Monopolies that lead to inefficiency need to be a concern for the government to be eliminated in formulating its economic agenda. There can be interpreted as no exception in port services supporting logistics distribution both domestically and internationally. Apart from being detrimental from an economic perspective, this action needs to be taken as a form of government commitment to international agreements. However, one day before implementing all existing provisions, Law Number 17 of 2008 concerning Shipping 
encountered obstacles. These obstacles followed the issuance of the Letter of the Minister of Transportation dated May 6, 2020, which essentially still gave rights to PT. Pelindo to carry out management indefinitely on the grounds of providing legal certainty and certainty in doing business.

According to the author, two fundamental problems arise regarding the issuance of the letter, namely legal uncertainty. What was initially intended to provide legal certainty and business certainty for existing Port Business Entities provides legal uncertainty in other aspects, namely related to the authority of the Port Authority, the basic principle being 'lex Superiore derogat lex inferiore' or higher regulations. Override the lower rules.

It is undeniable that the desired direction regarding port regulations is to create a climate of fair business competition by eliminating monopolies. However, some of the regulations do not seem clear. For example, in the case of a desire to create fair business competition, Transitional provisions should immediately implement a mechanism to conduct a transparent auction for all parties who wish to promote the port. However, Article 344 of Law Number 17 of 2008 states that adjustments must be made to the provisions as regulated in the law are ignored within three years.

There are no problems that can hinder the judicial implementation of Law No. 17 of 2008 because the letter issued by the minister of transportation does not affect implementing the provisions in the law. However, the Port Authority's position as the executor of several provisions in Law No. 17 of 2008 is structurally under the transportation minister. The institution that issued the letter.

\section{b) Operator Dual Role}

To overcome several problems that are still obstacles in realizing a healthy business competition climate at ports, efforts have been made to develop its implementation, one of which is the separation of roles between operators and regulators. PT. Indonesian harbor. (Pelindo), the Port Business Entity that previously acted as operator and regulator is no longer the regulator. Pelindo is positioned as a Terminal Operator and must have a Port Business Entity Permit.

Meanwhile, the regulator is held by the Port Authority, which used to be the Port Administrator. However, PT Pelabuhan Indonesia (Pelindo) is still operating as the sole operator in commercially operated ports. Apart from being the sole operator, Pelindo's position is what, in the author's opinion, provides the potential for Pelindo to continue to act as a regulator, moreover Pelindo also carries out the same business practices as other business entities that carry out their activities at the port. Pelindo's structure that allows it to act as an operator, a business actor, and even a regulator is part of a practice that may conflict with the principle of fair business competition. In addition, Pelindo also has several subsidiaries which are also engaged in its business area.

For example, before 2004, PT. Jakarta International Container Terminal (JICT) is purely a subsidiary of PT. Indonesian harbor. KPPU once canceled the agreement made by PT. Pelabuhan Indonesia II and PT JICT regarding the clause in the authorization agreement for the container terminal in Tanjung Priok, North Jakarta, because it is considered a strategic barrier for the entry of other business actors in the container terminal market. According to the Commission Council, the agreement is a form of delegation of monopoly rights that guarantees 75 percent of the market share of international container loading and unloading services at Tanjung Priok Port owned by PT Pelindo I1 as a BUMN to PT JICT as an 
Indonesian legal entity. This is considered an unfair implementation of privatization because it encourages monopolistic practices and unfair business competition.

Pelindo is an operator at the terminal that business people use, especially the sea transportation business, loading and unloading, and others in carrying out their activities. However, Pelindo also has business units, both internally and through its subsidiaries, which also carry out business activities at the terminals it operates to date. This is what then raises problems in practice. One of the things that can be referred to as this practice is the formation of a consortium of loading and unloading companies by Pelindo so that companies that are not members of the consortium cannot operate at the ports operated by Pelindo. No regulations are governing this matter other than those made by Pelindo.

The reason put forward by Pelindo, in this case, is to increase loading and unloading productivity. However, in other cases, it is not seen that in loading and unloading activities, the existing stakeholders are not only Pelindo as the operator, Pelindo as the loading and unloading business actor, and the existing loading and unloading company, but also the owner of the goods and "Pelindo as the regulator" which is undoubtedly very important. have an interest. Such a structure has the potential to cause inefficiency in existing business practices. The owner of the goods is the most disadvantaged party because of the many cost structures that must be paid.

In plain view, it will be strange if a body makes regulations intended for itself and other bodies conducting competition. There is evidenced by the practice of taking supervision fees in terms of loading and unloading. Or even if it is not proven, such a structure provides the potential for the business practices that are feared above. There is the basis for the application of competition law on a perse basis. Because it is not necessary to prove the consequences arising from the violation of the article, but it can be done by reading the potential for the consequences of the act to then take preventive actions through specific approaches.

\subsection{Efforts to Create Efficiency in Indonesian Ports}

As a solution to some of the inefficiency problems at the port, the author considers several steps that stakeholders can take. These solutions are intended to solve problems related to existing regulations but have not been implemented and other forms of problems. Therefore, it is necessary to implement regulations (law enforcement) on regulations that are considered good but have not been implemented, or improve or adjust existing regulations but are considered to cause many inconsistencies with what should be. In addition, the solutions offered can also be seen through economic analysis in law. There is essential because it is intended for port sustainability which is not only efficient but is always expected to increase, as also expressed by Richard Posner that: "An important question, already alluded to, in the economic analysis of law is whether and in what circumstances an involuntary exchange can confidently be said to increase efficiency."

\section{a) Repressive Effort}

In this sub-discussion, the author argues that juridical efforts to create efficiency at ports can be carried out through repressive measures, namely enforcement of competition law. The Business Competition Supervisory Commission has the authority to examine cases on its initiative, even though there are no reports. Apart from implementing existing provisions, especially in Law Number 5 of 1999, competition law enforcement is a form of the Indonesian government's commitment and consistency to implementing international agreements. 
Therefore, practices that are incompatible with the form of unfair business competition that the author has described previously must be eliminated. Because if the Monopoly still occurs, all activities at the port will not be completed and will still rely on one party, making costs unmanageable.

In competition law, there are two legal approaches to investigating prohibited acts or violations of Law Number 5 of 1999, namely the rule of reason method and the per se illegal method. The rule of reason method is used by the Business Competition Supervisory Commission to investigate an agreement and prohibited activity by further analyzing whether the agreement or action may result in unfair competition. On the other hand, the per se illegal approach is to declare every agreement or business activity as illegal without further proof of the effects.

Especially after the enactment of Law Number 17 of 2008, which should have previously been controlled by a single operator, the management of ports must be consistent to open up opportunities for the private sector and local governments as required by the law. The BUMN that previously acted as the sole operator and the regulator must now align with other Port Business Entities. Through these two regulations, the efforts expected to shape port efficiency can be achieved. In this case, what is needed by all stakeholders at the port is consistency in the implementation (law enforcement) of existing regulations (Ius Constitutum).

\section{b) Ius Constituendum}

In addition to the enforcement of existing regulations (Ius Constitutum), the author argues that juridical efforts to create efficiency at ports should also be discussed in 'Ius Constituendum' or laws that are needed in the future, either through the formation or revision of related regulations. The establishment of new regulations is intended to regulate issues related to institutional reorganization at ports. For example, the merger between harbor managers, port authorities, and port security under one roof is implementing the one-stop service system promoted.

In addition, the discourse of 'Ius Constituendum' should also be carried out through the revision of several counterproductive regulations. Some of them, such as the operator's authority in the field of business, should be separate. Articles that need to be revised in Law Number 17 of 2008 are Article 90 paragraph (3) letter g which reads "Provision of services for ships, passengers, and goods, as referred to in paragraph (2), consists of: (g). Provision of goods or services for loading and unloading of goods." This article later became the basis for the current operator to carry out loading and unloading business activities. If viewed, this regulation is certainly counterproductive to the previous article, namely Article 32 paragraph (1), which states that "Relevant service businesses as referred to in Article 31 paragraph (2) are carried out by a business entity established specifically for this purpose".

Apart from being counterproductive to the provisions in the previous article, the author intends to revise the article to develop a healthy business structure at the port. Due to the operator's position who can also carry out business practices outside the Provision of port services, of course, this can negatively impact specifically established to carry out loading. Unloading acti can monopolize loading and unloading activities because these activities are carried out in areas that are their service businesses in other fields, namely the service of providing places for loading and unloading. In addition to the revision of the article mentioned by the author, this discourse should also be addressed to the regulations under Law No. 17 of 2008, which also have an inefficiency effect in ports. 


\section{c) Port Governance Improvement}

In a study conducted by the Indonesian Insurance Council, there are at least three new forms of governance structures established under the Shipping Law of 2008, primarily in increasing competition and private sector participation as a form of efficiency in Indonesian ports that the author refers to:

a. Segregation of existing port assets so that they are split into different and competing companies. This approach, commonly known as segregation, is the preferred option in the privatization literature for applying direct competition to infrastructure sectors that state monostatic monopolies have hitherto dominated. In this case, however, it may be a very politically difficult choice to make. Of course, there will be a significant rejection of the law by some parties. There will be rejection at Pelindo. However, the government has clearly committed that no Pelindo assets will be sold to the private sector in response.

b. Investment. New in the new terminal. There provides an essential mechanism for capacity building and competition in the medium-long term. According to this DAI study, this will require increasing (or at least softening) the ceiling on foreign investment in port operations and essential infrastructure development by governments, as well as regulatory approvals, all of which will take time. However, as the author has mentioned earlier that there is nothing terrible in foreign investment. What the government needs to do is be careful in making contracts or granting concessions. In addition, an effort is also essential in the development and sustainable capacity development of many port authorities as government representatives at ports who will oversee port planning and operations and regulate access to vital port services and facilities.

c. It is likely to be implemented quickly to increase competition immediately. A form of efficiency in Indonesian ports is the rapid changes to special terminals or Terminals for Self Interest. to make it easier for them to accommodate general cargo. Currently, Indonesia has a lot of unused container and bulk cargo handling capacity at these private ports, which can be used directly to compete with Pelindo. Allowing at least a few ports to accommodate third-party cargo will provide short- to medium-term solutions to Indonesia's current port logistics problems while waiting for a longer-term solution through investment in new capacity enabled by the 2008 Shipping Law.

\section{d) BenchMarking with Ports of Other Countries}

In the discussion of the global economy, the thing that cannot be separated from economic liberalization is the free market discourse, which continues to be promoted as the agenda for the international economy. It is considered that this will further clarify the map of economic competition that will emerge in a country. Therefore, globalization and economic liberalization are important momentums at the world level, which seem to be echoed loudly by international economic actors lately. At every meeting, both on a regional and global scale, this is always directed at efforts to accelerate the process of integration into the world's free market.

About the port development strategy, each country has its strategy. However, some things that cannot be separated are the tangible results and achievements of the strategy. At the regional and even global level, several ports in Asian countries are ranked at the top in terms of logistics distribution achievements through their ports. For this reason, the author feels the need to conduct a benchmarking analysis with other countries that are considered superior to Indonesia. The country that the author feels is quite relevant to be used as some lessons, in this 
case, is Malaysia. Malaysia has at least two ports that are in the top ranking of the world's best ports.

\section{Conclusion}

There are several forms of obstacles in the form of business practices and government policies that ultimately cause or have the potential to cause inefficiency at ports. The authors divide these obstacles into two characteristics, namely juridical barriers and non-juridical barriers.

Legal barriers. These obstacles include obstacles that come from government policies in the form of regulations related to business practices in ports and the occurrence of violations of competition law. Non-juridical barriers. The resistance referred to is a basic structure that allows operators to have dual roles other than as operators, the inability of the private sector to invest, and the occurrence of illegal levies so that the costs incurred are charged to goods which, of course, triggers a high-cost economy. Even though business practices at Indonesian ports are carried out based on established regulations, the practice in the field often deviates from the existing system, especially in setting tariffs, levies, permits, and others that are considered to have an effect of inefficiency and high-cost economy. Although this second obstacle is non-juridical, it can have legal consequences. Law Number 5 of 1999 was made to prevent actions that lead to business structures that create entry barriers for competitors.

Several efforts can be taken to overcome the existing obstacles. Legal efforts that must be taken to create efficiency at ports can be carried out by enforcing laws against regulations deemed adequate but not yet effective and followed by optimizing the role of institutions that have the authority to supervise. In addition, revision efforts and judicial review should also be carried out on regulations that are considered counterproductive to the objectives to be achieved by the law, namely efficiency. In addition to these legal remedies, the authors also propose that several other efforts can be taken to create efficiency at ports, including the functioning of the role of port authorities as government representatives in granting concessions to Port Business Entities that are considered capable of managing, or another way,

namely re-improvement of governance that has been in place for a long time. There is going on.

\section{References}

[1] E. E. Supriyanto, Eksistensi Nilai-Nilai Pancasila Dalam Kebijakan Ekonomi Indonesia, 1st ed., no. September. Malang: Literasi Nusantara, 2020.

[2] T. Loya and G. Carden, Business intelligence and analytics. 2018.

[3] Jamilus, "The Importance OF ESTABLISHING FUNCTIONAL POSITION OF CORPORATE SUPERVISORATTHE MINISTRYOF LAWAND HUMAN RIGHTS Jamilus," J. Penelit. Huk. Jure, vol. 21, no. 2, pp. 175-186, 2021.

[4] A. Simbolon, "Prevention of monopolistic practices and unfair Business Competition through business Competition Supervision,” J. Leg. Ethical Regul. Issues, vol. 22, no. 1, p. 2019, 2019.

[5] K. Ishikawa, "The ASEAN Economic Community and ASEAN economic integration," J. Contemp. East Asia Stud., vol. 10, no. 1, pp. 24-41, 2021, doi: 10.1080/24761028.2021.1891702. 
[6] UU No 17 Tahun 2008 Tentang Pelayaran. .

[7] S. Magiera, "Indonesia's investment negative list:An evaluation for selected services sectors," Bull. Indones. Econ. Stud., vol. 47, no. 2, pp. 195-219, 2011, doi: 10.1080/00074918.2011.585947.

[8] P. Miraj, M. A. Berawi, T. Y. Zagloel, M. Sari, and G. Saroji, "Research trend of dry port studies: a two-decade systematic review," Marit. Policy Manag., vol. 48, no. 4, pp. 563-582, 2021, doi: 10.1080/03088839.2020.1798031.

[9] D. H. Rosenbloom and J. B. Gould, "Nonquantitative Research in Law and Public Administration: Approaches in the United States," Public Perform. Manag. Rev., vol. 44, no. 5, pp. 1031-1051, 2021, doi: 10.1080/15309576.2021.1886949.

[10] M. A. Girard, C. Régis, and J. L. Denis, "Interprofessional collaboration and health policy: results from a Quebec mixed method legal research," J. Interprof. Care, vol. 00, no. 00, pp. 1-8, 2021, doi: 10.1080/13561820.2021.1891030.

[11] A. Nur Hayati, "Analisis Tantangan dan Penegakan Hukum Persaingan Usaha pada Sektor E-Commerce di Indonesia," J. Penelit. Huk. Jure, vol. 21, no. 1, p. 109, 2021, doi: 10.30641/dejure.2021.v21.109-122.

[12] H. Cheeseman, Business Law: Legal Environment, Online Commerce, Business Ethics, and International Issues. Pearson Education. Inc, 2016.

[13] T. N. Mursitama and Y. Ying, "Indonesia's Perception and Strategy toward China's OBOR Expansion: Hedging with Balancing," Chinese Econ., vol. 54, no. 1, pp. 35-47, 2021, doi: 10.1080/10971475.2020.1809816. 